\title{
Von Krahl Theatre revisiting Estonian cultural heritage
}

\author{
Anneli Saro \\ Department of Literature and Folklore, University of Tartu \\ Ülikooli 18-230, 51014 Tartu, Estonia \\ e-mail: anneli.saro@ut.ee
}

\begin{abstract}
In the 1990s Estonia underwent a process of radical socio-political changes: a periphery of the Soviet conglomerate became a country with an independent political and economic life. The new situation also brought about a revision of cultural identity, which in the Soviet Union had been grounded primarily on the dichotomy between national and Soviet culture. Since these oppositions were rendered unimportant with the changed politico-economic conditions, a time of ideological vacuum followed. Estonia as an independent state and a cultural island between the East and the West turned its face toward Europe, questioning for its new or true identity in the postmodernising and globalizing society. In this article three productions of Estonian theatre as examples of identity construction will be analysed, investigating the rewriting of cultural heritage, intercultural relationships and implicit ideologies.
\end{abstract}

The 1990s were a period of new emerging subgroups and identities, so establishing a common national identity was no longer a primary concern. Sooner or later, almost all customary social structures and collective values and beliefs collapsed, forcing persons - as individuals and as a members of particular groups - to question their position in the rapidly changing society. The continuously fluctuating social and cultural contexts through which identities are constructed made the process particularly complicated and infinite. In the postmodern art practice classical texts and national myths are used mostly as material for deconstruction and free play with other cultural sources.

The Von Krahl Theatre (the first private theatre in Estonia, founded in 1992) with Peeter Jalakas acting as an artistic director, has 
been interested in performing and researching cultural myths about Estonians, while at the same time mixing them with modern international culture. Productions of Jalakas have been grounded on clear oppositions: our own — foreign, old — new, while 'our own' is usually the old and 'new' is mostly foreign. In "The Werewolf" (1998), for example, the characters and story-line of a play by August Kitzberg from early 20th century, depicting the social system and superstitions in Estonia at the beginning of the 19th century, is bound together with persons (characters and actors) from the end of the 20th century, while at the same time being conscious of the new technological world-view. "Estonian Games. Wedding" (1996) exposes the wedding traditions of an ethnic group, Setus, and Estonian history in the frame of a computer game. The latest production of the Von Krahl Theatre, "Estonian Ballads" (2004) uses the techniques of Japanese modern dance, Butoh, for visualising the world-view inherited with ancient folk songs.

In the present article I am going to concentrate on the above-mentioned productions, investigating the rewriting of cultural heritage, intercultural relationships and implicit ideologies.

Stuart Hall states:

In common sense language, identification is constructed on the back of recognition of some common origin or shared characteristics with another person or group, or with an ideal, and with the natural closure of solidarity and allegiance established on this foundation. In contrast with the 'naturalism' of this definition, the discursive approach sees identification as a construct, a process never completed — always 'in process'. (Hall 2000: 16)

But here an inevitable question arises - to what extent identification and identity construction depend upon a person's free and conscious will and to what extent the process depends on ideology, on discursive practices. There are eras and domains where one discursive practice clearly dominates the other and subjects' wills — such as the communist ideology of the Soviet regime, for example. Nowadays it is widely acknowledged that a person is constituted by a plurality of identities, some of them inscribed by social or cultural systems, and some of them taken on voluntarily. 
Like all signifying practices, it [identification $-A$. $S$.] is subject to the 'play' of différance. It obeys the logic of more-than-one. And since as a process it operates across difference, it entails discursive work, the binding and marking of symbolic boundaries, the production of 'frontier-effects'. It requires what is left outside, its constitutive outsider, to consolidate the process. (Hall 2000: 17)

Thus we can conclude that not only different identities but also the Others against which these identities are constructed should be taken into consideration.

Since Estonia has been an oppressed nation for most of the time of its notorious history, the identity of Estonians is constituted not so much in opposition to neighbours but in opposition to conquerors and rulers. The most important landmark of identity has been language, however since the Estonian language also indicated a social class up until the beginning of the 20th century, change in language often accompanied the ascent in social hierarchy. The second constituting component of the self-image has been the Estonian culture, of which the traditional peasants' culture was considered to be the most genuine and original, and also the most valuable, almost continuously until the beginning of the 1990s. An influential Estonian folklorist, Oskar Loorits, has treated the traditional culture as a static (using the word in a positive sense) element and foreign cultural influences as dynamic elements in Estonian culture. He admits in 1938 that these two flows lead to different directions but should be united to a common powerstation that would explore the heritage of the old folk culture for enriching modern life even on an international scale, and for transforming foreign loans and influences into an original creation (Loorits 2000a: 218). A slogan of the Soviet culture was "socialist by content, national by form", and results of this policy were generally quite ridiculous and artificial. Thus until the 1990s and even nowadays folk music and folk dance, national costumes and anniversaries, old beliefs and stories play an important role in the Estonian mind-set and way of life.

Analysing gender and queer identity, Judith Butler relies on the concept of 'performativity', which is relevant also in the context of performing the national identity.

In no sense can it be concluded that the part of gender that is performed is therefore the 'truth' of gender; performance as bounded 'act' is distinguished from performativity insofar as the latter consists in a reiteration of norms 
which precede, constrain, and exceed the performer and in that sense cannot be taken as the fabrication of the performer's 'will' or 'choice'; further, what is 'performed' works to conceal, if not to disavow, what remains opaque, unconscious, unperformable. (Butler 1993: 234)

Both individuals and communities need certain public identity statements that are often organised as performances or rituals in the broad sense of these terms. There is a repertoire of identification performatives (John Austin's concept - Austin 1975), which are widely known and repeatedly practised (verbal statements, dress code, attendance of particular events, etc.) and all these performances signify a corresponding identity. But performativity is not unalterably attached to preceding norms and traditions, quite the contrary, there is a certain individuality (conscious or unconscious) and contingency concealed in every performance, not to speak of intentional denials of norms. For example, in the end of 1980s, demonstrating one's national identity or sympathies became fashionable in Estonia. The use of national colours (blue-black-white) and elements of national costumes in clothing was one of the most evident ways of performativity that still left some room open for improvisation and individual differences. Such performances as signifiers of a larger concept can not fully cover all the range of meanings connected to the theme of identity, which is at least partly opaque or indefinable, but despite of them having a reductive nature, performances play an important role in confirmation and creation of communities. Thus performativity can be interpreted both as a kind of reiteration of the norm and a guarantee of consistency and coherence that is indispensable for a particular identity. The ways in which identities and performative strategies signifying them might be altered or modified will be analysed below by some examples from the repertoire of the Von Krahl Theatre.

\section{"The Werewolf" — confrontation of mentalities}

First and foremost, the Von Krahl Theatre has been a place for cultural exchange, a meeting place for liberal creators from different fields of art and different countries for interdisciplinary and intercultural cooperation. We'll start the examination of the aesthetics of theatre with a stage production of "The Werewolf" (orig. published in 1912) by 
August Kitzberg. This text has been a volume of school classics, a programme text in identity construction for Estonians during the 20th century, explicating its abiding value and changing meanings in numerous stage interpretations; deconstructive stagings of this (and other) plays have become a part of the programme of the Von Krahl Theatre and its leader Peeter Jalakas as well. The latter has staged "The Werewolf" twice: in 1992 the Von Krahl Theatre was inaugurated with its production and in 1998 the second version of the play was brought on the stage with a new troupe. The first production relied on the profanation and (post)modernisation of the tragic village life, using rock music, rollerskates, bullfights and other heterogeneous elements of popular culture. It was a rewriting of the topic of Estonian slavery and servility in an era of political and aesthetic freedom (Estonia became an independent state in 1991). The second interprettation was consciously more political and retrospective, according to Peeter Jalakas (Adorf 1998). (In the following analysis, I will rely on the video taken on the 9th of September, 1999, at the Drama festival in Tartu and on my own on the spot experience of the performance that took place in the summer 1998.)

The production starts with a video clip that introduces the actors in their everyday surroundings, preparing for rehearsals of the play. The attentive viewer, who knows that the main character, the werewolf, is called Tiina, notices the surprising similarity of the first names of actresses: Liina Vahtrik (plays Tiina), Tiina Tauraite, Katariina LaukTamm. (In the 1992 production Margus was played by Margus Värav, Mari by Mari-Liis Roos and Tiina Kristina Paškevičius.) In this way, the stage director has created a space for investigating the free play of différance and différence: Tiina as a generalised subject trapped in the opposition with society and her self, actresses re-enacting the existential situation as players and as characters. This interpretation is supported by a prologue presented by the author, August Kitzberg himself, who announces that the reason for gathering all these people is a sociological experiment through which the stage director attempts to answer the following questions: are the values and truths that were valid in ancient times, described in "The Werewolf", also relevant in this particular community of people? (The actors were chosen to be representative of the character types in the play.) Is the system that worked without failures in a society of that time and which is so accurately depicted in "The Werewolf" also transferable to our 
modern times? Or has something changed so radically that the problem is utterly unfamiliar to our society? Kitzberg himself has aesthetic interests in the project - what sort of possibilities are there for an authentic performance of the text in a time of stylistic pluralities of the modern theatre? Kitzberg opines that an authentic staging of his play is possible in principle.

August Kitzberg is sitting on a scaffold in the upper right corner for most of the duration of the play and tries to direct the game down on the stage by reading stage directions of his own play. His godlike physical position over the theatrical scene also gives him the role of a stage director, the creator of a fictional world. The author is not dead, as we might conclude after an acquaintance with Roland Barthes and his articles, instead his overt authority over the performance is unravelled on the stage on both the physical and the mental level.

There are four different areas on the frontal stage of black-box theatre: the central area is a play-ground for the actors; the upper right hand corner is a platform for the author, the director of the game; on the back of the stage there is a huge video screen, shaped rather like a window that extends the stage to different virtual or subconscious worlds, and a television on the right side of the stage. The latter has various functions and identities: sometimes it functions on the same level with the actors, who watch a programme about criminal activities (specifically about a wolf killing several animals), sometimes Kitzberg uses it as a tool (appears on the screen) for amplifying his comments, sometimes the actors use a video camera and the television for creating close-ups of characters' faces in their performance. A feminist reader interprets it as a male gaze following the female body that is taught to perform (Adorf 1998).

The fragmented and unsynchronised stage activities explicitly depict a sensation of a dispersed, unstable and bizarre world. There is also a figure on the video screen that strengthens the feeling — an old man coiling up red rope on a snowy landscape that might be interpreted as a demarcation of borders (state borders inside and between (?) the Soviet Union and Europe, as well as frontiers between different mentalities and clear notions, and between fiction and reality on the level of production).

Different times and identities ('real' and fictional) are also mixed on a personal level. The production depicts a postmodern world-view with its obligatory identity crises. Whereas identities are quite stable 
and coherent on the fictional level, they become fragmented and/or fluid on the performative level. Theatre as a certain model of community especially reflects and illustrates social roles and role playing in general. For example, Tiina Tauraite as an actress has to perform two fictional roles close to her own nature, Mistress and Grandmother. Even though she tries to impersonate different characters, some of her lines sound strangely modern and ambivalent, and as such dropping between the past and the present discourse. Multiplied identities and the (subconscious) heritage of the past as one of the constructive factors for this phenomenon is also explicitly questioned in the production.

Tiina Tauraite: Who has drawn off the curtains? [It remains unclear whether she means stage curtains or window curtains. $-A$. $S$.] The curtains must be in front of the window; someone might cast an evil eye.

Erki Laur: Did you say it as yourself, as Mistress or as Grandmother?

Tiina Tauraite: My grandmother spoke like that.

The central character of the play, Tiina, has a double identity; she is a human being and a werewolf. In the metatheatrical level she has become an object and a symbol of superstition, which is believed in and denied at the same time. (The actress performing the role is called Tiina by other actors even though her real first name is Liina. Also, her acting style allows us to deduce that she is more tightly connected with the fictional world than the other performers, or she is checking the limits of fictional and real.) Tiina's identity in the play is built up on her Otherness, on clear physical and behavioural differences from other characters - she has dark hair and eyes, she is lively and cheerful, as opposed to blonde hair, blue eyes, modesty and slowness of the others as typical (chosen, wishful) representatives of the Estonian nation. In the production this physical confrontation is extinguished. The actresses, playing Tiina and Mari, opponents in a love affair and in their respective mentalities, who are naturally (of course, in the postmodern era of corporal manipulations we should prefer here the construction 'in public life') quite blonde, perform dark-haired and relatively inward-turned persons, similarly to most of the others. The appearance of the whole troupe indicates that nowadays blonde hair and blue eyes are rather exceptional characteristics of 
the local people and represent stereotyped and outdated visual representations of Estonians.

The otherness in general and this particular case especially (the werewolf) is frightening, but also admirable and desirable. The actor playing the humpbacked Master (Erki Laur) implores his beloved Tiina to make him an animal, a werewolf, so that he too could be free, equal with Tiina and able to escape to the forest. He refuses his human identity. An Estonian theatre researcher living in New York (multipleidentity!), Mardi Valgemäe, has commented upon this problem already in 1971:

It seems as if Kitzberg would want to say that light is actually dark and the dark-haired Tiina is the real original Estonian type, whose Dionysian thirst for life is not suffocated by Christian piety obtruded to our nation. (On one level, the conflict in "The Werewolf" is presented as a conflict between Christianity and superstition.) (Valgemäe 1995: 69-70)

The quotation also illustrates the search for authenticity from the preferable primordial times that we discussed earlier.

Dispersal and deferral of fictions, events, spaces, meanings and identities comes to the fore with distinctive clarity in the bonfire scene on Midsummer Night. Some of the first representations of Estonians as a nation in the theatrical discourse have been folk traditions. At the turn of the 18th and 19th centuries, when researchers began to divide the socio-cultural reality up into different national cultures, they became interested in the peculiarities and "spiritual" characteristics of nations and national cultures (Sevänen 2004: 57-58). Interest in native people also spread among the Baltic German nobility in the beginning of the 19th century, resulting in productions in the Tallinn City Theatre, depicting local language and customs. The most favoured topics were bees, Midsummer Night bonfires and weddings, enabling the presentation of 'authentic' songs, dances, customs and national costumes. Such a practise has been, and still is quite common in colonised countries. It should be noted that the Midsummer Night bonfire is still the most relevant, alive and widespread national tradition in Estonia at the present time.

Different world-views and traditions are explicitly opposed in the bonfire scene: one of the actors proposes to organise a primitive pagan ritual, another offers a modern urbanised conception, paraphrasing a well-known folk song: "Bring us petrol, bring us diesel, bring us 
tyres..." But on the stage a rather postmodern or theatrical version is carried out, with multicoloured dust brushes as fireworks and jumping over the bonfire (= television set showing burning logs), in accordance with the old custom of Midsummer Night. Simultaneously with this activity, the movie "The Werewolf" is shown for entertainment on the other television. This pseudo-romantic movie, shot by Estonian emigrants living in Canada, where Estonian is spoken with a heavy accent and supported with English subtitles, evokes the feeling of a truly campy style and makes both the actors and the audience roar with Homeric laughter. One more layer is added to the heterogeneous intertextual discourse of "The Werewolf" — half-mythological marsh creatures, urgveelased, from a short story “The Werewolf” by August Gailit appear behind the window (on the screen). Gailit warns us that these scary beings bear the sign of death and their appearance forebodes the death of a domestic animal. (Later it is proposed that urgveelased are in fact trumps who watch the television from behind strangers' windows.)

The party gains momentum and the stage activity turns into a Dionysian celebration: on the video screen, there is a mechanically dancing trumpeter, familiar from a well-know vodka label "Viru valge", acting as a sign of intoxication and mental inebriation, ${ }^{1}$ Tiina and Margus are dallying around in front of the TV showing a bonfire like wolf cubs bringing out their werewolf potential, etc. In a state of released subconscious another implicit connotation of the notion of werewolf is opened: the actor playing Kitzberg, who is physically present on the stage during the whole performance, is now shown in another television. With the monotonous voice of a news announcer he tries to dissect the relationship between Estonia and Russia and the circumstances of Russians in Estonia, the most problematic topic in Estonian foreign policy, and by which an attempt is made to evoke a subconscious feeling of guilt among the local populace. Although the speech of Kitzberg/news announcer/politician is buried by the tumult of the party and it is difficult to follow his train of thought, the spectator nevertheless concludes from the political commentary an allusive assertion that the fear of werewolves (Others, strangers) has today changed into the apprehension and hostility towards Russia and Russians, so that "they [Russians? - A.S.] must be burnt on the stake

The critic Mihkel Mutt (1998) suggested that this can be as a sign for Estonia, referring to the public discussion that was going on. 
for the preservation of the blue-eyed [the word also carries a connotation of naiveté - A.S.] people as long as they exist". Mounting is one of the most well known and widespread methods for modifying messages ('truth') and manipulating with audiences. This television transmission problematises both the form of the presentation (how does a neutral commentary about a common livingspace for different nations turn into a hysterical Nazi manifestation?) and content (for example, where does the vague border between nationalism and Nazism run? In Estonian these words are even more similar: natsionalism-natsism).

In any case, the national myth about the slavery of Estonians, lasting for 700 years, is abased in the production through the sublime and pathetic incantation of words by the Grandmother, an ideologist of Estonian ideals and the only light-haired person in the group. Actress Tiina Tauraite (the last name is Lithuanian in origin) recites an anthem for conservativity, patience, long suffering and blood, following the rhythm and melody of Tchaikovsky's "Piano Recital No 1". Compiling Kitzberg's sentences, she is stressing that there is not a drop of foreign blood in our veins, it is pure and there are generations upon generations of light-haired people standing in a line, all of them having suffered greatly. The pathos and exorbitance give the incantation a clearly ironic meaning.

The influence of television as a mediating and manipulative medium comes more clearly to the fore later on in an interview with a countryman whose foal was torn by a wolf. Answering an ambiguous question, "did the wolf resemble a human being", the respondent discusses a pantheistic world-view in which the two are generally quite similar but that a wolf is more beautiful than a man. The reporter summarises the conversation as follows: "It is evident from the testimony of Mr Kaarel Kivest that the wolf who tore the foal was clearly a human being. Everyone can draw this conclusion on their own." The retort seems to suggest a freedom for interpretation but still leads the recipient on the path of misunderstanding. There is an obvious parallel with a legal procedure concerning a 77 years old shepherd Gaston Dominici, described by Roland Barthes in "Mythologies" (Barthes 2004: 55-60). Both stories describe a conflict between different linguistic discourses, between ways of thinking and living. 
The topic of a time of transitions and a relativization of values is activated several times in this production. Already in the beginning, the half-blind Grandmother/Tiina Tauraite uses the words of Kitzberg:

[...] the world is full of things that are unreachable to the mind and senses. You watch and watch but you cannot see anything. The old religion/faith made a difference between good and bad: there were evil sorcerers and clever people who knew more than others. The new religion/faith makes no difference, everything is the same - the same kind of witches! But yet some good and bad is concealed underground like little veins of water. Good and bad that do not make sense. (Kitzberg 1969: 10)

The play by Kitzberg offers a general existential, situational and linguistic pattern (it is non-hierarchical and flexible) which has been carried further by cultural institutions and genes. 'Pattern' can be interpreted as a factor of social and cultural stability and continuity but which is also open to certain changes - a pattern can be filled with different substances. Certain structural changes are also possible, although they are strongly resisted. Yet the deconstruction of a pattern confirms and strengthens the vitality of a structure, or at least activates it in the memory and consciousness of a community. The characters/actors of "The Werewolf" rebel against the traditional ending of the play and against the power of the author to direct their lives. Thus Mari and Margus go to the attic to confront Kitzberg, similar to characters from a Pirandello play ("Six Characters in Search of an Author" or "Tonight We Improvise") and demand changes to be made in the conception of characters and that in the end, love would win all social obstacles. Mari/Katariina Lauk declares the failure of the social experiment of testing the suitability of the system described in the play for modern times:

"The Werewolf" is not written about humans, but about talking dolls. We are like signs that are supposed to mean something and may-be once we did mean something, but not anymore, since everything is changed. The world is not divided into black and white, us and strangers, the Tammaru's people and urgveelased, any more. Everything is much more complicated! When dolls revive, everything will change.

Margus protests against the pattern of life and decisions prescribed by his ancestors, he marries Tiina out of passion, instead of rational calculations and prescribed traditions. He shouts at the Grandmother: 
"I do not care about your race and brush. ${ }^{2}$ We draw new borders, me and Tiina, with the blood of our love. Rammstein!"

The time of transitions also raised questions about the role and structure of theatre in Estonia. Thus the actors in "The Werewolf" are discussing several issues on a meta-theatrical level: are state subsidies for theatre justified, what would happen if one day the system would be turned down, what kind of needs theatre would meet, etc. There is a plenitude of different opinions but the conclusion is that theatremaking is possible without state support and theatre's most important task is to create an emotional contact between people.

We may conclude that "The Werewolf" is an assiduously typical postmodern production, yet these kinds of deconstructive ironical metatheatrical games with a national heritage and cultural myths have been replayed in every single culture, because only in this way can local peculiarities confront global structures.

\section{"Estonian Games. Wedding" — engagement of cultures}

"Estonian Games. Wedding" (for the first time played in 1996, staged by Peeter Jalakas and Priit Raspel) is created on the principles of a computer game and with an authentic Setu female choir "Leiko", six actors and a huge computer screen. Setus, an ethnic group living mostly in south-east Estonia, as well as on the other side of the Estonian-Russian border, have received special attention at home and abroad because of their living folk song tradition and by their special national costumes that clearly differ (at least those of women) both from Estonian and from Russian traditions. Due to several differences in behaviour and life-style, the word 'Setu' has also obtained pejorative connotation and the ethnic group has been often excluded from the original national body.

Estonian folk songs are traditionally divided into two groups: authentic Estonian folk songs that are based on "primary rhyme" (alliterations and assonances) and parallelism of thought; songs with end rhyme were domesticated here through German chorales only in the beginning of the 19th century (Loorits 2000b). Until the 1990s, the

2 Linguistic word play: suguvõsa (meaning 'family' in Estonian) = sugu (race; sex) $+v \tilde{s} a$ (brush) - A. $S$. 
old stratification of songs has been more valued than the newer ones, mostly for their authenticity. Folk songs of Setus are based on alliterations and assonances and thus they are considered to be old and original.

Peeter Jalakas has admitted a constant conflict between two different mediums in theatre: human beings and a video screen. He finds that the problem results partly from the collective nature of theatre art - usually one person is responsible for video images, another for stage directions and these two persons and two mediums are rarely working in unison. Ideally video and stage activity should form an integrated whole that mostly depends on the location of the centre of gravity in the production. When the moving picture is alone then its centre of gravity is situated mostly behind the screen, depth of space opens up to the other side of the screen. In theatre the intensive place should be located in front of the screen - the picture must be sufficiently sparse for filling the space between spectators and the screen with energy (Jalakas 2004: 10-11). Speaking about the core of energy on the stage also concerns the centre of the spectators' attention and producers' intentions in directing it.

In "Estonian Games. Wedding" the computer images are insistently flat ethnographic drawings depicting Estonian living conditions through changing times and socio-cultural influences - thus the centre of gravity of the production was meant to be situated in front of the screen and the source of the energy should be the choir of 7 women. But most of theatre critics and other spectators stated that their centre of attention was attached to the screen since most of the information originated from this space. First, verbal information on the screen was written in plain English, contrary to the songs performed in Setu language and actors consciously mumbling their lines in Estonian, probably for imitating naturally spoken Estonian. Second, all of the characters played by the six actors enter the stage through the screen, upon which they are introduced humorously or self-ironically from a national point of view. Third, television and computer game strategies and stylistics were the most familiar for the majority of the spectators. Critic Raivo Kelomees declares in his article "The screen as the main character":

In the case in question, the screen can be understood as big mother whose apertures are used by actors [the author probably means the characters, for actors are only vehicles $-A$. S.] for arriving to the real reality (stage 
conventionality). From here we might proceed to psychoanalytically influenced discussions about 'sex' of the screen and about stage director as the 'father' whose phallic indicating cursor is moving on the screen... (Kelomees 1996)

But the screen can also be considered as condensed national memory or knowledge about the historical past that is in part relatively independent and fixed (facts and chronology) and partly constantly changing, depending on its human or material carriers, demanding both retaining and rewriting. A single subject, such as a perceiving spectator, can never possess the whole information about the national body but when certain details pop up on/out of the screen from this discourse he/she as a member of the community knows intuitively its meaning and significance.

While the informative computer game tell us a story about the Estonian history from 1130 up to the present day, singers perform Setu wedding rituals in parallel. Both the narrated history and the performed wedding can be considered isomorphic - grand narratives formally based on observing and strengthening the tradition but concentrating on change and transition by content. But in the production the diachronic perspective is expressed only in the screen, on the stage time is almost congealed: a bride is constantly waiting for her groom, a father wants to match his son, brothers are fighting for the girl, a war is going on somewhere and one of the brothers has an obligation to go to the war, and for that reason the girl can not get married. There are many speculations, derived from a language with no future tense (Masing 1993: 53) or from the life-style and folklore (Loorits 2000b: 97) that the epic, future-oriented forms are extraneous to the Estonian mentality. Thus they concentrate on the present moment, on descriptions of static situations and feelings.

Estonians lack the Faustian urge for infinity, the feeling of constant travel and change, they do not fight with time in time like an Indo-German. - Instead, he lays the time over himself, the future exists only so far as far it can be done in the past. Of course, this also is a certain urge for infinity but in another form, instead of fighting development, a simple step over the limits/borders of time, outside of motion. (Masing 1993: 53)

At last the marriage act is performed in the production but the date onscreen refers to the future, the year 1998 (the performance analysed here was recorded on Oct. 31,1997$)$, or perhaps to the positive and 
ever-existing potential for success, not situated in the mythical past or in the dreamed future.

I would like to mention a detail which in a manner questions the topic presented in "The Werewolf". In "Estonian Games. Wedding" the bride represented as a stereotypic figure of an Estonian woman blonde, charming, smiling, silent, a doll-like being, performed by Kristina Paškevičius (a Lithuanian surname!). The reception of the production in the festival Theater Der Welt in Berlin, an Estonian living in Germany for the 9th year mentions that that the word Estland (Estonia in German) denotes something very blonde and Nordic yet at the same time also something from the East (Kasterpalu 1999). Thus the conventional sign of the bride was probably also supposed to stress to the representational/performative nature of the character in context of the slightly ironic production, yet at the same time it reinforced the stereotype.

In contrast to the bride and the other fictional characters on and in front of the screen, the Setu signers have an untheatrical, perhaps even a natural, but at the same time quite an inward-turned effect on the stage, which is an artificial environment for the singers and not their regular performance space. Therefore constant conflicts appeared on the stage between the artificial (technology, 2-dimensional 'space' on the screen, theatre discourse in general, acting as such) and natural (non-actors, performing rituals, folk songs in an original rendition), new and old, borrowed (technology, theatre as an institution and an art form) and own (songs, dances and rituals, even their originality is questionable). Many people reacted as follows: "They [the Setu singers - A. S.] symbolise consistency of the national identity, a selfconfident mental strength that still lasts and continues to do so from century to century" (Liivrand 1999). Thus a marginal exotic ethnic group and its peculiar culture became a source for national pride, admiration and partly even identification, although they represented a difference in language, place of residence, lifestyle, worldview, as well as age, compared to most of the spectators. All this happened in a time when Setus themselves had been striving for cultural independence and recognition by Estonians. And this is only one aspect of the complicated notions 'national identity' or 'us versus others' in a globalizing and individualising world. 


\section{"Estonian Ballads" - merger of cultures}

"Estonian Ballads" (2004), the latest production of the Von Krahl Theatre, uses the techniques of Japanese modern dance, Butoh, for visualising a world-view inherited with ancient folk songs. This became a significant and non-debatable event in the Estonian cultural field, but Peeter Jalakas has confirmed the stability of his intentions and working methods from the end the 1980s, although the means of expression as well as the context of reception have changed (Jalakas 2004: 10). Jalakas reached a level of artistic maturity and perfection already in 2003 when he brought out a post-modern dance production "The Swan Lake" in the Von Krahl Theatre together with Sasha Pepeljajev, famous Russian choreographer.

"Estonian Ballads" unites several different discourses: music for the folkloric ballads was written by the famous 'nationalist' composer Veljo Tormis already in 1980, the production is staged by an avantgarde director Peeter Jalakas, Butoh dancer Aki Suzuki and the wellknown conductor Tõnu Kaljuste, the troupe consisted of actors, dancers and singers. "Estonian Ballads" was performed in a huge barn built during the Soviet regime located some 60 kilometres from Tallinn. Whereas the aural side (ballads and music) of the production stressed the archetypical and national topics, the visual level relied almost entirely on Butoh aesthetics: faces and costumes of performers covered with clay, slow minimalist movements, naked bodies, dancing Aki Suzuki etc. Other dancers were carrying the bodily techniques inscribed on them by European/Estonian cultural tradition and training methods but at the same time exposed new, learned technique of Butoh that seemed artificial and strange at the first glance but managed to display some hidden phenomenological qualities of the local pre-Enlightenment society and national/tribal values. Since the ballads chosen for the production mostly represented a female point of view and the main characters were all women, the performances might lead also to feminist interpretations, though this possibility was not realized in the reception process. (Which is in fact characteristic of all three productions analysed here.)

Thus the task and result of the collage of cultures was not some sort of a postcultural production (of course, I can not totally deny the possibility of this reception strategy) where the origin and original meaning of different elements is reduced or forgotten. "Estonian 
ballads" might be classified mainly as an intracultural project, proceeding from Pavis' definition, according to which intracultural "refers to the search for national traditions, often forgotten, corrupted or repressed, in order to reassess the sources of a style of performance, to situate it better in relation to external influences and to understand more deeply the origins and the transformation of its own culture" (Pavis 1996: 5-6). Both "The Werewolf" (the version staged in 1998) as well as "Estonian Games. Wedding" can be gathered under this notion because deconstructive strategies were used not for demolition but for revisiting the national cultural heritage.

The conclusion of the analysis of the aesthetics of the Von Krahl Theatre and of staging the Estonian national identity might be asserted in a manner similar to William Butler Yeats almost a century ago our world is caught between the two eternities of blood and soul, blood: reflecting the tribal past, and soul: anticipating the cosmopolitan future (Segers 2004: 80). But some complicated questions remain in the air: will Estonians manage to remember and value their tribal past (as well as other sources for creating cultural differences), and will they succeed in the preservation of their national body geographically and genetically or will they become a mere display in an ethnographic ghetto/museum.

\section{References}

Austin, John L. 1975. How to Do Things with Words. Cambridge: Harvard University Press.

Adorf, Margit 1998. Libe hunt. Sirp 20.10.

Bathes, Roland 2004. Dominici ehk Kirjanduse triumf. In: Barthes, Roland, Mütoloogiad. Tallinn: Varrak, 55-60.

Butler, Judith 1993. Bodies that Matter: On the Discursive Limits of Sex. London: Routledge.

Hall, Stuart 2000. Who needs 'identity'? In: Gay, Paul du; Evans, Jessica; Redman, Peter (eds.), Identity: A Reader. London: SAGE Publications, 15-30. Jalakas, Peeter 2004. Vastab Peeter Jalakas. Teater. Muusika. Kino 11: 5-19.

Kasterpalu, Margus 1999. Von Krahl mängib Eesti ajaloo ja sini-must-valgega. Postimees 7.07.

Kelomees, Raivo 1996. Ekraan kui peategelane. Postimees 4.10.

Kitzberg, August 1969. Libahunt. Draama viies vaatuses. Tallinn: Eesti Raamat. 
Liivrand, Harry 1999. Eesti mängud. Pulm publikumenukas Amsterdamis. Eesti Ekspress 9.10.

Loorits, Oskar 2000a. Eesti kultuuri struktuurist, orientatsioonist ja ideoloogiast. In: Loorits, Oskar, Meie, eestlased. Tartu: Ilmamaa, 208-259.

- 2000b. Eesti rahvalaulude kultuurajalooline tagapõhi. In: Loorits, Oskar, Meie, eestlased. Tartu: Ilmamaa, 95-102.

Masing, Uku 1993. Hüpoteetilist eesti keele psühholoogiast. In: Masing, Uku, Vaatlusi maailmale teoloogi seisukohalt. Tartu: Ilmamaa, 51-55.

Mutt, Mihkel 1998. Libahunt — mäng, koostvõtt ja poleemika. Eesti Ekspress 2.10 .

Pavis, Patrice 1996. Introduction: Towards a theory of interculturalism in theatre?

In: Pavis, Patrice (ed.), The Intercultural Performance Reader. London: Routledge, 1-21.

Segers, Rien E. 2004. The underestimated strength of cultural identity between localising and globalising tendencies in the European Union. In: Kupiainen, Jari; Sevänen, Erkki; Stotesbury, John A. (eds.), Cultural Identity in Transition. Contemporary Conditions, Practices and Politics of a Global Phenomenon. Delhi: Atlantic Publishers \& Distributors, 64-92.

Sevänen, Erkki 2004. The study of cultural identity: Development and background of a multi-disciplinary field of research. In: Kupiainen, Jari; Sevänen, Erkki; Stotesbury, John A. (eds.), Cultural Identity in Transition. Contemporary Conditions, Practices and Politics of a Global Phenomenon. Delhi: Atlantic Publishers \& Distributors, 33-63.

Valgemäe, Mardi 1995. Rituaalteatrist ja "Libahundist". In: Valgemäe, Mardi, Linn ja teater. Lavamärkmeid mitmelt maalt. Tallinn: Vagabund, 59-72.

\section{Театр фон Краля переигрывает эстонское культурное наследие}

В 1990-е гг., в связи с изменением социально-политической ситуации в Эстонии, произошли сдвиги и в местном национальном идентитете. Если в Советском Союзе эстонский культурный идентитет строился в основном на противопоставлении советского и национального, то в новых условиях эстонцы ощущали свое промежуточное состояние между Востоком и Западом, им вновь нужно было определиться как в смысле национального, так и государственного идентитета в постмодернистском и глобализирующемся мире. В этот период уменьшилась роль национального идентитета в самоопределении эстонцев, важнее стали новые возникающие субгруппы. В художественной практике наступило время национальных мифов и деконструирования классики. Театр фон Краля (первый частный эстонский театр, основанный в 1992 г.) и его художественный руководитель Пеэтер Ялакас в нескольких своих 
постановках расследовали культурные мифы эстонцев, противопоставляя свое-чужое и старое-новое. В статье анализируются три постановки Ялакаса: “Оборотень” (1998), “Эстонские игры. Свадьба” (1996) и “Эстонские баллады” (2004), в которых (во всех трех) интерпретируются основы национальной культуры.

\section{Von Krahli teater eesti kultuuripärandit ümber mängimas}

1990. aastatel seoses Eesti sotsiaal-poliitilise situatsiooni muutumisega leidsid aset nihked ka siinses kultuurilises identiteedis. Kui Nõukogude Liidus oli eestlaste kultuuriline identiteet üles ehitatud peamiselt sovjetliku ja rahvusliku vastandusele, siis uutes tingimustes tajuti oma vahepealsust Ida ja Lääne vahel ning tuli taas küsida oma rahvusliku, aga ka riikliku identiteedi järele (post)moderniseeruvas ning globaliseeruvas maailmas. Sel perioodil vähenes rahvusliku identiteedi osatähtsus eestlaste enesemääratlemisel ning olulisemaks muutusid uued tekkivad subgrupid. Kunstipraktikas saabus rahvuslike müütide ja klassika dekonstrueerimise aeg. Von Krahli Teater (esimene Eesti erateater, asutatud 1992) ja selle kunstiline juht Peeter Jalakas on mitmetes oma lavastustes uurinud eestlaste kultuurilisi müüte, vastandades oma ja võõrast ning vana ja uut. Artiklis analüüsitakse semiootiliselt kolme Jalaka lavastust: "Libahunt" (1998), "Eesti mängud. Pulm" (1996) ning "Eesti ballaadid" (2004), mis kõik tegelevad rahvusliku kultuuri aluste interpreteerimisega. 